\title{
Factors Related to Enuresis in 5 to 6 Years Old Children in Public Health Centre, Padang Indonesia
}

\author{
Dwi Novrianda ${ }^{1}$, Bunga Permata Wenny ${ }^{2}$, Dahlia Lara Sikumalay ${ }^{3}$ \\ \{dwinovrianda@nrs.unand.ac.id ${ }^{1}$, ina.bunga@gmail.com ${ }^{2}$, dahliasikumalay@gmail.com ${ }^{3}$ \} \\ Faculty of Nursing, Universitas Andalas, Padang, Indonesia
}

\begin{abstract}
Enuresis (bedwetting) is a common disorder in which children wet the bed consciously while they should have had control of the bladder. Prevention of this case is highly important, hence the impact of enuresis on child development can be overcome. Family history, psychological stress, constipation, and poor toilet training can lead to enuresis. This study aims to discover factors related to enuresis in children aged 5-6 years in Padang City. The research type is quantitative with the method is analytic and an approach of cross-sectional study. The samples used in this study involved 178 children who were 5 and six years old. These were taken by applying incidental sampling technique. The data collection tool was questionnaires including several factors regarding enuresis in children; this consisted of a family history questionnaire (IACAPAP), psychological stress (PSS-C), constipation, toilet training, and other questionnaires. The data analysis used was a Chi-square test. The results showed that less than half of a total number of the children had enuresis $(34.8 \%)$ and there was a relation among family history, constipation, toilet training (p-value $=0.000)$ and psychological stress $(\mathrm{p}$-value $=0.003)$ with enuresis in children. This thesis suggests that parents should pay more attention to their children's health such as stress and constipation, and nurses as educators are expected to provide information for parents about stress, constipation and implementation of toilet training in children in order to reduce the incidence of enuresis.
\end{abstract}

Keywords: Constipation, Enuresis, Family History, Psychological Stress, Toilet Training.

\section{Introduction}

Preschool age is included in early childhood consisting of children aged 3 to 6 years [1]. At preschool age, physical development is slower and relatively sedentary. The body system should be mature and already trained with toileting [2].

At the age of 4 years, the child can go to the toilet alone, the child should have been able to control the urination, the child no longer wet the day or night [3].

The diagnosis of enuresis according to Diagnostic and Statistical Manual of Mental Disorders (DSM IV-TR) is chronological age of at least five years and occurs at least twice a week within three months [3].

The prevalence of enuresis varies with the age of the child. Wolfish (2009) states that the prevalence of enuresis is $16 \%$ occurring at age five years, $13 \%$ at age six years, $10 \%$ at age eight years, $5 \%$ at age ten years. Moreover, the prevalence of enuresis is greater at the age of 56 years, which is $34.4 \%$ of 140 children [4].

The cause of enuresis is unclear, but several factors can cause enuresis. Soetjiningsih [3] mentions factors that contribute to primary enuresis, genetic factors, maturation disorders 
(developmental delay), disruption of antidiuretic hormone production, urodynamic disorders (small bladder capacity), and sleep disturbances. The factor contributes to the occurrence of secondary enuresis psychological stress. Moreover, the constipation factor is also a contributing factor to secondary enuresis [5], [6].

Enuresis will result in the child's inferiority and depression [7]. Hockenberry [8] explains that enuresis can affect self-esteem if the parental response to the disorder is harsh or punishing. Enuresis causes stress with a high percentage in children [9]. In some cases, enuresis may be a trigger for child abuse [8].

Secondary enuresis is also affected by the disease experienced by the child. Asmadi [10] mentions that toilet training is one of the factors associated with enuresis.

\section{Methods}

This research type is quantitative with analytical method and Cross-Sectional Study approach that is research to study the correlation dynamics between risk factors and effects, by the approach of observation or data collection at one time (point time approach) [11].

The population in this study were children aged 5-6 years in 9 kindergartens (TK Musa Enda, TK Ridhotullah, TK Fadillah Amal, Adzkia Kindergarten, Ar-Raudhah Kindergarten, TK Pembina, TK Mardhiyah, TK Nurul Yaqien, TK Auladul Jannah) in Bandar Bandar Kecamatan Lubuk Padang urban village of Padang, amounting to 320 children. The sampling technique used was incidental sampling, with a sample size of 178 children. Inclusion criteria: 1) Children aged 5-6 years in Bandar Buat urban village, 2) Children and mothers are willing to be respondents, 3) Children is accompanied by mothers during research. Exclusion criteria: 1) Children taking diuretic drugs, 2) Children with diabetes, spina bifida, and seizure abnormalities, 3) Children with mental retardation. Research on the factors related to enuresis in children aged 5-6 years in kindergarten in Bandar Create District Work Area Puskesmas Lubuk Kilangan Padang conducted in August 2017. Data collection took place from August 1 to August 9, 2017. Data collection was conducted on mothers who have children aged 5-6 years who attend at Kindergarten Moses Enda, TK Ridhotullah, TK Fadillah Amal, Adzkia Kindergarten, Ar-Raudah Kindergarten, Kindergarten TK, Mardhiyah Kindergarten, Nurul Yaqien Kindergarten, and Kindergarten Auladul Jannah. The sample in this study is a mother who has children aged 5-6 years, amounting to 178 people.

\section{Results}

Table 5.1 shows that more than half of children aged six years are $50.6 \%$ and more than half of girls are $56.2 \%$. In table 5.2 it can be seen that more than half of respondents did not experience enuresis $(65.2 \%)$. In Table 5.3 it can be seen that more than half of respondents have no family history of enuresis (77\%). In table 5.4 it can be seen that most respondents experience mild stress $(90.4 \%)$ and no children are experiencing severe stress. In table 5.5 it can be seen that most children do not experience constipation (92.7\%). Table 5.6 shows that most children have a history of diapers $(68.5 \%)$ and only some do not use diapers (31.5\%). In Table 5.7 it can be seen that half of the respondents experienced adequate toilet training (50.\%).

Based on Table 5.8 of 41 children with a family history of enuresis, $95.1 \%$ also had enuresis, and only $4.9 \%$ of children with a family history of enuresis did not experience enuresis. 
Of the 137 children with no family history of enuresis, only $16.8 \%$ had enuresis, and $64 \%$ had no enuresis. Further statistical test results obtained p-value $0.000<\alpha 0.05$, so it can be concluded there is a significant relationship between family history with enuresis.

Based on table 5.9 can be seen from 17 children who experienced moderate tress, $70.6 \%$ had enuresis, and $29.4 \%$ did not experience enuresis. Of the 161 children with mild tress, only $31.1 \%$ experienced enuresis, and $68.9 \%$ did not experience enuresis. The results of further tress ic test obtained p-value $0.003<\alpha 0.05$, so it can be concluded there is a significant relationship between psychological tress with enuresis.

Based on table 5.10 can be seen from 13 children who experience constipation, $92.3 \%$ experience enuresis and only $7.7 \%$ who do not experience enuresis. Of the 165 children who were not constipated, only $30.3 \%$ had enuresis, and $69.7 \%$ had no enuresis. Further statistic test results obtained p-value $0.000<\alpha 0.05$, so it can be concluded there is a significant relationship between constipation with enuresis.

Based on table 5.11 can be seen from 48 children with toilet training less, $70.8 \%$ experience enuresis and $29.2 \%$ do not experience enuresis. Whereas of 89 children with enough toilet training, only $24.7 \%$ experienced enuresis and $75.3 \%$ did not experience enuresis. As well as from 41 children with good toilet training, only $14.6 \%$ experienced enuresis and $85.4 \%$ did not experience enuresis. Further statistical test results obtained p-value $0.000<\alpha 0.05$, so it can be concluded there is a significant relationship between toilet training with enuresis.

\section{Discussions}

The results showed that $34.8 \%$ of children had enuresis. The results of this study are consistent with the research of Fatmawati and Mariyam [12], where 31\% of the 67 preschoolers over the age of 5 in Semarang experience enuresis. However, the current study results are higher than Solanski's study reporting that $20.4 \%$ of 5-6-year-olds in India experience enuresis [4]. Similarly, Latif in Africa reports that $20.4 \%$ of children experience enuresis [13]. Further research by Windiani in Bali reported only $10.9 \%$ of children who experience enuresis [14].

In the current study, it is likely to be influenced by several aspects such as the child's age and the sex of the child. Enuresis occurs mostly in boys [10]. In this study the percentage of children who experienced enuresis greater in girls is $51.6 \%$, this is because in this study most of the respondent's female sex, which is as many as 100 children (56.2\%). Meanwhile for the age of children, in this study more than half of the children aged six years $(50.6 \%)$. A child can not control her urination completely until she is 4 or 5 years old [15]. So the results of this study showed less than half of children with enuresis (34.8\%).

The current study shows that more than a few children have no family history of enuresis. This is contrary to previous studies that reported only a small proportion had a family history of enuresis [14], [16], [17]. Family enuresis history is a genetic factor of enuresis [14] — the role of genes located on chromosome $12 \mathrm{q}$ (gene ENUR-2) in the occurrence of enuresis. In addition, genes carrying these enuresis properties are also found on chromosome $13 \mathrm{q}$ (ENUR-1) and 22 (ENUR-3) [3]. This inheritance is generally autosomal dominant. However, this study did not carry out further genetic testing, such as chromosome examination, so that the future needs to be identified as the presence of these genes in children through biomedical research. Furthermore, this study reported that the majority of siblings experienced enuresis $(83 \%)$ and only a small percentage had a history of parents with enuresis (17\%). 
Further research generally showed children experience mild stress. The results of this study are in line with Fatmawati in Semarang, that is, most children experience mild stress (61.7\%) [12]. Ozkan in Turkey only divides into two groups: stress and no stress with only $0.4 \%$, and Kurniawan (2013) in Pekalongan which states only 34.3\% of children who experience stress [18]. Like adults, children can also experience stress even more vulnerable to stress than adults [14]. Stress as the result of an event or a series of experiences that are interpreted negatively, the experience can be an extraordinary event (parents died, natural disaster) or daily events (fever, difficult homework, problems with friends or you) [19]. The results of this study are in line with the causes of stress presented by Widyarini, unfulfilled expectations, fears, alien or unexpected new situations, which in this study the child has just entered kindergarten and is in a new environment [20]. Moreover, children who experience stress will more often feel angry [19].

The study also reported that children generally do not experience constipation. In line with the results of Windiani study in Bali which stated that only 7.8\% of children constipated [14], Sureshkumar in Australia with only 5.7\% of enuresis [21], Kurniawan in Pekalongan, $17.1 \%$ of children have constipation [22]. However, the study in Canada reported more than half (57.54\%) of children had constipation [23]. The cause of constipation is the lack of consumption of high fiber foods, beverage intake or fluid or irregular bowel habits [24]. In this study, children with constipation had a hard bowel habit and twice a week or less. While for food and liquid consumption is not examined further in this study.

Next, research shows that only a quarter of children get good toilet training. The results of this study differ from Kurniawan in Pekalongan who reported more than half $(71.5 \%)$ had good toilet training [22]. Toilet training in children is an attempt to train the child to be able to control the urination and defecation [26].

\subsection{Family history and enuresis}

Based on the result of the research in table 5.8, it was found that percentage of children with enuresis were greater in children with family history with enuresis, 39 children (95.1\%) than children with no enuresis family history of 23 children (16.8\%). Further statistical test results obtained a significant relationship between family history and enuresis ( $\mathrm{p}$-value $=0.000$ ). Majority of respondents with a family history of enuresis were enuresis siblings of 34 children (83\%), only seven children with a history of parents with enuresis (17\%).

Family enuresis history is a genetic factor of enuresis [14]. Genetic predisposition with the same family history is the most frequent cause [26]. Several studies have shown that enuresis is associated with a history of enuresis in the elderly or siblings [3].

The results of this study are consistent with the [14] study in Bali, suggesting a relationship between family history and enuresis, in which the history of a father or sibling with enuresis significantly increased enuresis, 5.3 and 23.3, respectively. This is also in line with Doganer research results in Turkey where $50.9 \%$ of enuresis children have a family history with enuresis [16]. Von Gontard in Germany also expressed a relationship between family history and the incidence of enuresis [17]. The results of Ozden [18] study in Turkey were $44.9 \%$ of children with enuresis parents also experienced enuresis, and $50 \%$ of children with enuresis relatives also experienced enuresis. 


\subsection{Psychological stress and enuresis}

Based on the result of the research in table 5.9, it was found that percentage of children who experienced enuresis was greater in children who had moderate stress $(12,6 \%)$ compared to children with mild stress (50\%). Further statistical test results obtained a significant relationship between stress and enuresis ( $p$-value $=0.003$ ).

Enuresis can be a manifestation of psychological stress in children. The source of psychological stress on the child's enuresis is when the child experiences a migration to a new environment, sister's birth, hospitalization, or child abuse. This situation causes regression of urinary control [3]. Stressful events as children learn to control microstructures can affect learning and severe stress later in life can lead to the return of enuresis [26].

The results of this study are in line with the Ozkan study in Turkey which states a relationship between stress and enuresis in which $44.7 \%$ of enuresis-experienced children are also under stress [18]. Fatmawati research in Semarang on the relationship of stress with enuresis in preschool children in semarang, with the result there is a relationship between stress with the incidence of enuresis in children [12]. This research is also in line with research Kurniawan in Pekalongan stating the relationship between stress and enuresis, amounted to 83.3\% of children who experience stress enruesis [22].

\subsection{Constipation and enuresis}

Based on the results of the research in table 5.10, it was found that percentage of children who experienced enuresis was greater in children with constipation of 12 people (92.3\%) compared with constipation of 50 people $(30.3 \%)$. Further statistical test results found a significant relationship between constipation and enuresis $(p$ value $=0.000$ ). Constipation is the release of hard stool, rare defecation, or difficulty removing the feces. Constipation causes direct pressure by the feces of the bladder, causing enuresis. Constipation is also said to cause the urinary capacity to shrink so that enuresis occurs [23]. Constipation is one condition that can reduce bladder capacity, and constipation occurs in more than $50 \%$ of children with secondary nocturnal enuresis [5]. The results of this study are consistent with the study of Akyol in Turkey which states significant constipation rates occur simultaneously in patients with enuresis, with a result of $67 \%$ of patients with enuresis also experiencing constipation [27]. Similarly, Kurniawan's research in Pekalongan on enuresis occurrence, one of them from constipation in 35 children, showed that there was a relationship between constipation and enuresis occurrence, from 8 children with constipation of 7 children experiencing enuresis (87.5\%) [22].

\subsection{Toilet training and enuresis}

Based on the result of the research in table 5.11, it was found that percentage of children who experienced enuresis were greater in children with less toilet training that was 34 people (70.8\%) compared with children with good and good toilet training, 22 people (24.7\%) children with toilet enough training and 6 people (14.6) children with good toilet training. Further statistical test results indicate a significant relationship between toilet training and enuresis ( $\mathrm{p}$ value $=0.000$ ) .

Toilet training in children is an attempt to train the child to be able to control the urination and defecation [25]. Toilet training performed well and correctly can stimulate the neurological development of children who control the urinary sphincter so that children can develop well in controlling elimination, thereby reducing the risk of enuresis [29]. By Asmadi mentioned that toilet training is one of the factors associated with enuresis [10].

The result of this research is in line with research of Kurniawan in Pekalongan about enuresis occurrence, one of them from toilet training in 35 children, shows that there is a 
relationship between toilet training with enuresis incidence, where $90 \%$ of children with toilet training do not experience enuresis [22]. This study is also in line with Arifin's study in Medan of 37 children about the ability of children to implement elimination from toilet training, showing that there is a relationship between toilet training and the ability of children to eliminate, 10 out of 15 children with less toilet training ( $66.7 \%$ ) are not able to eliminate well, in which one of the abilities of the child in elimination is the child's ability to control the elimination of the urine well which can be seen with the child not wetting or enuresis [29].

\section{References}

[1] Potter, P.A \& Perry, A.G. (2005). Buku Ajar Fundamental Keperawatan: Konsep. Proses, dan Praktik, edisi 4, volume 1. Alih Bahasa: Yasmin Asih, dkk. Jakarta: EGC

[2] Supartini, Y. (2004). Konsep Dasar Keperawatan Anak. Jakarta:EGC

[3] Soetjiningsih. (2015). Tumbuh Kembang Anak Edisi 2. Jakarta: EGC.

[4] Solanski, A \& Desai, S.G. (2014). Prevalence and risk factors of nocturnal enuresis among school age children in rural areas. International Journal of Research in Medical Sciences, 2(1), 202-205.

[5] Mindell, J.A., Owens, J.A. (2010). A Clinical Guide to Pediatric Sleep Diagnosis and Management of Sleep Problems. Philadelphia. Lippincott Willianss \& Wilkins.

[6] Prasadja, A. (2009). Ayo Bangun. Bandung: Penerbit Hikmah

[7] Brough, H., Alkurdi, R., Nataraja, R., Surendranathan, A.(2008). Rujukan Cepat Pediatri \& Kesehatan Anak. Jakarta: EGC

[8] Hockenberry, M., Wilson, D. (2011). Wong's nursing care of infants and children, ninth edition. USA:Elsevier

[9] Ellington, E.E \& McGuinness, T.M. (2012). Mental Health Consideration in Pediatric Enuresis. Journal of Psychosocial Nursing, 50 (4), 41-45.

[10] Asmadi. (2008). Teknik Prosedural Keperawatan: Konsep dan Aplikasi Kebutuhan Dasar Klien. Jakarta: Salemba Medika

[11] Notoadmodjo, S. (2010). Metodologi penelitian kesehatan. Jakarta: PT Rineka Cipta.

[12] Fatmawati, L. \& Maryam. (2013). Hubungan Stres dengan Enuresis pada Anak Usia Prasekolah di RA Al Iman Desa Banaran Gunung Pati Semarang. Jurnal Keperawatan Anak, 1 (1), 24-29

[13] Latif, A.M.A., Osman, E., Abdelaziz, A., Shaker, S., Nageib, H. (2004). Pattern of Primary Nocturnal Enuresis In Primary School Children (First Grade) In Assiut City. African Journal of Urology, 10(1): 22-29.

[14] Windiani, I.G \& Soetjiningsih. (2008). Prevalensi dan Faktor Risiko Enuresis pada Anak Taman Kanak-Kanak di Kotamadya Denpasar. Sari Pediatri, 10 (3) 121-157

[15] Nelson. (2012). Ilmu Kesehatan Anak (Nelson Textbook of Pediatrics). Jakarta: EGC.

[16] Doganer, Y.C., Aydogan, U., Ongel, K., Sari, O., Koc, B., Saglam, K. (2015). The Prevalenc and Sociodemographic Risk Factors of Enuresis Nocturna among Elementary School-age Children. Journal of Family Medicine and Primary Care, 4(1): 39-44.

[17] Von Gontard A, Niemczyk J, Weber M, Equit M. (2015). Specific behavioral comorbidity in a large sample of children with functional incontinence: report of 1001 cases. Neurourolody and Urodynamics;34:763-768.

[18] Ozkan, S., Durukan, E., Iseri, E., Gurocak, S., Maral, I., Bumin, M.A. (2010). Prevalence and risk factors of monosymptomatic nocturnal enuresis in Turkish children. Indian Journal of Urology, 26(2): 200-205.

[19] Ibung, D. (2008). Stres Pada Anak. Jakarta: Gramedia.

[20] Widyarini, N. (2009). Relasi Orangtua \& Anak. Jakarta: Elex Media Komputindo.

[21] Sureskhumar, P., Jones, M., Caldwell, P.H.Y., Craig, J.C. (2009). Risk Factors for Nocturnal Enuresis in School-Age Children. The Journal Of Urology, 175, 2254-2262. 
[22] Kurniawan, A. (2013). Hubungan Antara Stres, Toilet Training dan Konstipasi dengan Kejadian Enuresis pada Anak Usia 4-5 tahun Di TK Aba Poncol Kelurahan Poncol Kecamatan Pekalongan Timur Kota Pekalongan. Skripsi Universitas Muhammadiyah Semarang.

[23] Robson WLM, Leung AKC, Howe RV. (2005). Primary and secondary nocturnal enuresis: similarities in presentation. Pediatrics;115:956-9.

[24] Wijayakusuma, H. (2006). Tanaman Obat untuk Penyakit Anak. Jakarta: Pustaka Populer Obor.

[25] Hidayat, A.A.A. (2012). Pengantar Ilmu Keperawatan Anak 1. Jakarta: Salemba Medika

[26] Meadow, R., Newell, S. (2005). Lecture Notes: Pediatrika Ed.7. Jakarta: Erlangga.

[27] Akyol, I., Ates, F., Soydan, H., Senkul, T., Karademir, K., Baykal, K. (2010). An Overlooked Issue In Children Presenting With Enuresis: Constipation. Journal Of Pediatric Urology, 6(1), S66.

[28] Wong, D.L., Hockenberry-Eaton, M., Wilson, D., Winkelsten, M.L., Schwartz, P. (2008). Buku ajar keperawata pediatric Ed.6. Jakarta: EGC.

[29] Arifin, R.S. (2010). Hubungan Toilet Training Terhadap Kemampuan Anak Dalam Melakukan Eliminasi di Kel. Dwikora Kec. Medan Helvetia. Tesis: USU 